\title{
PENGARUH ROA, NPM dan DER TERHADAP CORPORATE SOCIAL RESPONSIBILITY (CSR)
}

\section{(Studi Empiris Pada Perusahaan Pertambangan yang Terdaftar Pada BEI tahun} 2014-2018)

\author{
Yubiharto'; Nurlaela Rakhma Hastuti $^{2}$ \\ STIE Tamansiswa Banjarnegara Jl. Mayjend Panjaitan No. 29 Banjarnegara, 53414 \\ Email : hyubi@yahoo.co.id ${ }^{1}$; nurlaelarahmahastuti@gmail.com ${ }^{2}$
}

\begin{abstract}
The problem in this research is the low level of CSR disclosure or social responsibility in mining companies, even though in reality it is stated in the law that every company is required to disclose social responsibility. This research is an empirical study on mining companies listed on the Indonesia Stock Exchange in the 2014-2018 period. The purpose of this study was to determine the effect of ROA, NPM and DER on CSR. This research is quantitative descriptive. The data used are secondary data with direct collection through the company's annual report. This sampling technique uses a separate sample criteria taken from mining companies that disclose CSR using the GRI index. Data analysis in this study used multiple linear regression analysis with SPSS 24 software. The results of this study indicate that partially the ROA variable has no significant positive effect on CSR, while the NPM and DER variables have a significant positive effect on CSR. However, all variables simultaneously influence CSR.
\end{abstract}

Keywords: ROA, NPM, DER, CSR.

\section{PENDAHULUAN}

\section{Latar Belakang}

Indonesia adalah negara yang kaya akan sumber daya alam, maka dari itu banyak sumber daya alam yang bisa dimanfaatkan sebagai peningkatan ekonomi dan perbaikan sistem perkenomian di Indonesia. Di era reformasi seperti ini sektor pertambangan merupakan salah satu

sektor penting dalam perekonomian Indonesia, terutama di Masterplan

Vol. 11, No. 1, Juli 2020, Halaman 59-70
Percepatan dan Perluasan Pembangunan Ekonomi Indonesia sebagai penghasil devisa (MP3I, 2011-2025).

Banyak Perusahaan-perusahaan di Indonesia secara resmi yang berlombalomba untuk memanfaatkan sumber daya alam yang ada untuk meningkatkan perekonomian Indonesia. Beberapa perusahaan tersebut adalah perusahaan go public yang tercatat pada BEI (Bursa Efek Indonesia). Pada saat ini banyak perusahaan yang semakin berkembang, maka pada saat itu pula kesenjangan sosial 
mulai timbul dan kerusakan lingkungan juga menjadi dampak negatif bagi perusahaan pertambangan.

Mutia et al dalam Istiana (2016) corporate social responsibility (CSR) muncul akibat adanya modernisasi masyarakat yang sudah memahami bahwa aktivitas yang dilakukan oleh perusahaan dapat membawa dampak negatif pada lingkungannya. Apalagi hal ini sangat dekat dengan aktivitas yang dilakukan oleh perusahaan di era saat ini yang sering melibatkan masyarakat. Dalam proses produksinya perusahaan pertambangan mau tidak mau akan menghasilkan limbah produksi, sangat erat hubungannya dengan masalah pencemaran lingkungan. Proses produksi yang dilakukan juga mengharuskannya untuk memiliki tenaga kerja bagian produksi sehingga masalah keselamatan kerja juga harus diperhatikan.

Pengungkapan laporan tanggung jawab sosial (CSR) perusahaan digambarkan dalam laporan tahunan (annual report) perusahaan itu sendiri. Perusahaan pertambangan merupakan salah satu contoh perseroan yang berkaitan dengan sumber daya alam sebagaimana disebutkan dalam pasal 74 ayat 1 dalam Undang-undang No.40 Tahun 2007 tentang perseroan terbatas (PT). Perusahaan Pertambangan yang terdaftar di BEI dari tahun 2014 sampai dengan tahun 2018 bertambah 9 perusahaan sehingga menjadi 48 perusahaan dan yang sudah mengungkap corporate social responsibility (CSR) baru 28 perusahaan sehingga jika disebut dalam presentase hanya $58 \%$. Data tersebut bertahan sampai dengan tahun 2018, sehingga menunjukkan bahwa perusahaan yang terdaftar pada sektor pertambangan di Bursa Efek Indonesia sampai dengan tahun 2018 juga belum sepenuhnya mengungkapkan tanggung jawab sosial (corporate social responsibility).

Total perusahaan dalam 5 tahun terakhir masih kurang dari $60 \%$ perusahaannya yang telah mengungkapkan tanggung jawab sosial perusahaan (corporate social responsibility). Jika mengikuti pasal 74 ayat 1 dalam Undang-undang No.40 Tahun 2007 tentang perseroan terbatas (PT), diharapkan semua perusahaan pertambangan untuk mengungkapkan tanggung jawab sosial perusahaan, namun pada faktanya sampai dengan tahun 2018, tidak semua perusahaan pertambangan di Indonesia mempublikasikan pengungkapan tanggung jawab sosial perusahaan atau corporate social responsibility (CSR).

Yuansyah (2012) mengungkapkan Perusahaan tambang dikenal sebagai perusahaan pencemar lingkungan. Oleh karena itu, perusahaan tambang harus menerapkan program tanggung jawab sosial berupa program yang dapat mengurangi dampak kerusakan lingkungan dari usaha pertambangan yang mereka lakukan. Sejatinya, pertambangan merupakan industri yang dapat memberikan manfaat ekonomi tinggi. Penggalian terhadap sumber-sumber kekayaan alam berupa mineral dan batubara mampu memberikan sumbangan yang signifikan terhadap sumber keuangan negara. Namun terdapat fenomena yang menggambarkan bahwa perusahaan tambang merupakan perusahaan yang sensitif pada dampak pencemaran lingkungan. Fenomena 
tersebut adalah gencarnya isu dari LSM lingkungan yang kerap mengindentikkan pertambangan dengan kehancuran lingkungan.

Syahnas (2013) mengungkapkan kinerja keuangan perusahaan merupakan factor penting untuk menilai keseluruhan kinerja perusahaan itu sendiri. Profitabilitas juga disinyalir sebagai factor yang mempengaruhi luas pengungkapan yang dilakukan perusahaan. Hubungan antara profitabilitas perusahaan dengan pengungkapan tanggung jawab social perusahaan telah menjadi anggapan dasar untuk melakukan pengungkapan tanggungjawab social dalam kegiatan perusahaannya, sehingga semakin tinggi tingkat profitabilitas yang dihasilkan perusahaan, maka akan diharapkan semakin besar kesadaran perusahaan dalam menjalankan corporate social responsibility (CSR).

Kinerja keuangan merupakan suatu gambaran untuk menilai perkembangan suatu perusahaan. Perusahaan dengan kinerja keuangan yang baik akan menghasilkan laba yang maksimal sehingga memiliki tingkat pengembalian modal atau bahkan laba yang tinggi. Kinerja keuangan yang paling mudah untuk dinilai adalah kemampuan perusahaan untuk memberikan keuntungan dari asset, ekuitas, maupun hutang. Faktanya dalam perusahaan pertambangan masih perlu diperhatikan untuk mengungkapkan CSR berdasarkan kinerja keuangan yang ada. Kasmir (2017) ukuran kinerja keuangan perusahaan dapat diukur dengan beberapa rasio, maka dari itu dalam penelitian ini penulis mengambil rasio keuangan berdasarkan kemampuan perusahaan menghasilkan laba dengan total asset (ROA), kemampuan perusahaan menghasilkan laba dengan total penjualan (NPM), dan kemampuan perusahaan mengembalikan hutang atau kewajiban dengan total modal (DER).

Dalam perusahaan pertambangan hal yang paling berhubungan dengan pengungkapan CSR adalah tingkat laba dan hutang, untuk mengetahui tingkat kesuksesan perusahaan adalah dengan melihat dari laporan keuangan dan laporan tahunan yang didalamnya terdapat data rasio keuangan yang jelas dan akurat, dengan mengukur tingkat menghasilkan keuntungan dengan menggunakan total aktiva yang ada yaitu return on aset (ROA), seperti halnya menurut (Munawir, 2007) adalah return on assets (ROA) selain berguna untuk keperluan kontrol, juga berguna untuk keperluan perencanaan, kemudian selanjutnya mengukur tingkat menghasilkan keuntungan dengan total penjualan yaitu net profit margin (NPM), serta mengukur tingkat mengembalikan total kewajiban menggunakan total modal yang ada yaitu debt to equity ratio (DER).

Dari fenoma gap diatas bisa dibandingkan dengan hasil dari penelitianpenelitian terdahulu yaitu pada penelitian Natalia, Johny, dan Joanne (2018) yang menyatakan return on asset dan net profit margin tidak berpengaruh signifikan terhadap corporate social responsibility (CSR). Berbeda dengan penelitian Sari (2012) yang menemukan bahwa profitabilitas berpengaruh positif signifikan terhadap corporate social responsibility (CSR).

Kemudian untuk pengungkapan corporate social responsibility (CSR) melalui debt to equity ratio, dalam penelitian Resti dan Indah (2012) 
menemukan bahwa leverage yang diukur dengan debt to equity ratio (DER) tidak berpengaruh signifikan terhadap corporate social responsibility (CSR), sedangkan penelitian Cahya (2010) menyatakan variabel leverage yang diukur dengan debt to equity ratio (DER) berpengaruh positif dan signifikan terhadap pengungkapan corporate social responsibility (CSR).

Dari fenomena riset diatas maka peneliti tertarik untuk mengetahui perkembangan pengaruh ROA, NPM, dan DER terhadap CSR, sehingga penulis menulis skripsi ini dengan judul "Pengaruh ROA, NPM, dan DER Terhadap Corporate Social Responsibility (CSR) (Studi Empiris Pada Perusahaan Pertambangan Yang Terdaftar Pada BEI Tahun 2014-2018)".

\section{Rumusan Masalah}

1. Apakah ROA berpengaruh terhadap CSR ?

2. Apakah NPM berpengaruh terhadap CSR ?

3. Apakah DER berpengaruh terhadap CSR ?

4. Apakah ROA, NPM, dan DER berpengaruh terhadap CSR ?

\section{Tujuan Penelitian}

1. Untuk Mengetahui Apakah ROA berpengaruh terhadap CSR

2. Untuk Mengetahui Apakah NPM berpengaruh terhadap CSR

3. Untuk Mengetahui Apakah DER berpengaruh terhadap CSR

4. Untuk Mengetahui Apakah ROA, NPM, dan DER berpengaruh terhadap CSR

\section{METODE PENELITIAN}

\section{Lokasi Penelitian}

Obyek Penelitian yang akan dilakukan adalah Perusahaan Pertambangan yang sudah terdaftar di Bursa Efek Indonesia (BEI) periode tahun

Vol. 11, No. 1, Juli 2020, Halaman 59-70
2014-2018 diambil dari situs resmi BEI yaitu www.idx.co.id.

\section{Jenis Penelitian}

Jenis Penelitian yang akan dilaksanakan yaitu penelitian kuantitatif deskriptif.

\section{Variabel Penelitian}

Pada penelitian ini terdapat 3 variabel bebas yaitu return on aset (ROA) (X1), net profit margin (NPM) (X2), debt to equity ratio (DER) (X3), dan 1 variabel terikat yaitu corporate social responsbility (CSR) (Y).

\section{Definisi Konsep dan Definisi Operasional Variabel}

a. CSR

CSR merupakan suatu mekanisme pengintegrasian isu sosial dan isu lingkungan ke dalam operasi perusahaan dan kemudian mengkomunikasikannya dengan para stakeholder dan publik lainnya. (Darwin, 2006), sehingga rumus yang digunakan untuk menentukan CSR adalah jumlah item yang diungkapkan oleh perusahaan dibagi Jumlah item pengungkapan CSR.

b. ROA

ROA merupakan satu bentuk rasio profitabilitas yang dimaksudkan untuk dapat mengukur kemampuan perusahaan dengan keseluruhan dana yang ditanamkan dalam aktiva yang digunakan untuk operasi perusahaan dalam menghasilkan keuntungan. (Munawir, 2007), sehingga rumus yang digunakan untuk menghitung ROA adalah laba bersih dibagi total aktiva dikalikan $100 \%$. c. NPM

NPM merupakan Margin laba bersih merupakan ukuran keuntungan dengan membandingkan antara laba setelah bunga dan pajak dibandingkan dengan penjualan. Rasio ini menunjukkan pendapatan bersih perusahaan atas 
penjualan (Kasmir, 2014), sehingga rumus yang digunakan untuk menghitung NPM adalah laba bersih dibagi total penjualan dikalikan $100 \%$.

\section{d. DER}

DER merupakan rasio yang dipakai untuk mengukur utang dengan ekuitas. Rasio ini dihitung dengan cara membandingkan antara seluruh utang, termasuk utang lancar, dengan seluruh ekuitas perusahaan. (Kasmir, 2014), sehingga rumus yang digunakan untuk menghitung DER adalah total kewajiban dibagi total modal dikalikan $100 \%$.

\section{Populasi Sampel dan Teknik Sampel}

a. Populasi Penelitian

Populasi adalah keseluruhan subyek penelitian (Arikunto, 2010). Populasi dalam penelitian ini adalah seluruh perusahaan pertambangan yang terdaftar dalam Bursa Efek Indonesia pada tahun 2014-2018 sejumlah 48 perusahaan dan perusahaan pertambangan yang sudah mengungkapkan CSR berjumlah 28 perusahaan.

b. Teknik Sampel

Pengambilan sampel yang representatif dalam penelitian ini adalah menggunakan teknik sampling purposive sampling dengan teknik sampling jenuh. Adapun Kriteria Sampel yang digunakan:

\section{Tabel 1}

\begin{tabular}{|c|c|c|}
\hline NO & Keterangan & Jumlah \\
\hline 1 & $\begin{array}{l}\text { Perusahaan Pertambangan } \\
\text { yang terdaftar di BEI tahun } \\
\text { 2014-2018 }\end{array}$ & 48 \\
\hline 2 & $\begin{array}{lrr}\text { Perusahaan } & \text { yang } \\
\text { mengungkapkan } & \text { CSR } & \text { 2014- } \\
2018 & & \\
\end{array}$ & 28 \\
\hline 3 & $\begin{array}{l}\text { Perusahaan yang } \\
\text { mengungkapkan CSR melalui } \\
\text { laporan keberlanjutan dengan } \\
\text { menggunakan index GRI } \\
\text { selama 5 tahun berturut-turut }\end{array}$ & 7 \\
\hline & sampel yang digunakan $7 \times 5=$ & \\
\hline
\end{tabular}

\section{Teknik Analisis Data}

Adapun teknik analisis data yang digunakan dalam penelitian adalah analisis regresi linier berganda sederhana dengan menggunakan SPSS, dan rumus yang digunakan adalah :

$$
\hat{\mathrm{Y}}=\mathrm{a}+\mathrm{b}_{1} \mathrm{X}_{1}+\mathrm{b}_{2} \mathrm{X}_{2}+\ldots .+\mathrm{bnXn}+\varepsilon
$$

\section{HASIL DAN PEMBAHASAN}

Hasil uji asumsi klasik

a. Uji Normalitas

Tabel 2

Hasil Uji Normalitas

\begin{tabular}{lr}
\hline & \multicolumn{2}{c}{$\begin{array}{c}\text { Standardized } \\
\text { Residual }\end{array}$} \\
\hline $\mathrm{N}$ & 35 \\
Kolmogorov-Smirnov Z & .803 \\
Asymp. Sig. (2-tailed) & .539 \\
\hline
\end{tabular}

a. Test distribution is Normal.

Dari tabel Kolmogorov-Smirnov test nilai sig. (2-tailed) yang dihasilkan sebesar 0,539>0,05. Hal ini berarti nilai residual terstandarisasi dinyatakan menyebar secara normal.

b. Uji Multikolinearitas

Tabel 3

Hasil Uji Mulitikolinearitas

\begin{tabular}{llcc}
\hline & & \multicolumn{2}{c}{ Collinearity Statistics } \\
\cline { 2 - 4 } Model & \multicolumn{2}{c}{ Tolerance } & VIF \\
\hline 1 & (Constant) & & \\
& ROA & .248 & 4.038 \\
& NPM & .272 & 3.680 \\
& DER & .734 & 1.362 \\
\hline
\end{tabular}

a. Dependent Variabel: CSR

Dari tabel diatas masing-masing variabel memiliki nilai tolerance $>0,10$ dan nilai $\mathrm{VIF}<10$, maka dapat disimpulkan pada model regresi yang terbentuk tidak terjadi gejala multikolinearitas.

c. Uji Heteroskdastisitas

Tabel 4

Hasil Uji Heterokedastisitas 
Dari tabel diatas masing-masing variabel memiliki nilai signifikasi $>0,05$ maka dapat disimpulkan model regresi tidak terjadi gejala heteroskedastisitas.

\section{d. Uji Autokolerasi}

Tabel 5

Hasil Uji Autokolerasi

\begin{tabular}{|c|c|c|c|}
\hline Model & $\mathrm{R}$ & $\begin{array}{c}\mathrm{R} \\
\text { Squar } \\
\mathrm{e}\end{array}$ & Durbin-Watson \\
\hline 1 & $.506^{\mathrm{a}}$ & .256 & 2.286 \\
\hline
\end{tabular}

Berdasarkan nilai hitung DurbinWatson diatas sebesar 2,286 lalu hasil ini akan dibandingkan dengan nilai dl dan du yang diperoleh dari table Durbin-Watson (terlampir). Jumlah sampel sebanyak 35 dengan 3 variabel independen diperoleh nilai dl sebesar 1,238 dan nilai du sebesar 1,653. Syarat penelitian untuk dapat dinyatakan bebas dari autokorelasi adalah $\mathrm{du}<\mathrm{d}<(4-\mathrm{du})$. Berdasarkan nilai hitung diatas, dapat dinyatakan bahwa penelitian ini terbebas dari masalah autokorelasi.

\section{Hasil uji Hipotesis}

a. Uji f

Table 6

Hasil Uji f

\begin{tabular}{|c|c|c|c|c|c|}
\hline Model & $\begin{array}{l}\text { Sum } \\
\text { of } \\
\text { Squar } \\
\text { es }\end{array}$ & Df & $\begin{array}{c}\text { Mean } \\
\text { Square }\end{array}$ & F & Sig. \\
\hline 1 Regression & .408 & 3 & .136 & 3.565 & $.025^{\mathrm{a}}$ \\
\hline Residual & 1.182 & 31 & .038 & & \\
\hline Total & 1.589 & 34 & & & \\
\hline
\end{tabular}

a. Predictors: (Constant), DER, NPM, ROA

Berdasarkan table diatas dapat kita lihat bahwa uji simultan ini menghasilkan nilai f hitung sebesar 3,565 >f table $(2,87)$ dan signifikan hitung $0,025<0,05$, maka ROA, NPM dan DER secara simultan berpengaruh terhadap CSR.

\section{b. Uji Koefisien Determinan}

Vol. 11, No. 1, Juli 2020, Halaman 59-70

\begin{tabular}{lrr} 
Model & \multicolumn{1}{l}{ T } & \multicolumn{1}{l}{ Sig. } \\
\hline (Constant) & 1.908 & .066 \\
ROA & -.697 & .491 \\
NPM & 1.927 & .063 \\
DER & .553 & .584 \\
\hline
\end{tabular}

Table 7

\begin{tabular}{|c|c|c|c|}
\hline \multicolumn{4}{|c|}{ Hasil Uji Koefisien Determinan } \\
\hline & & $\begin{array}{c}\mathrm{R} \\
\text { Squar }\end{array}$ & \\
\hline Model & $\mathrm{R}$ & $\mathrm{e}$ & Durbin-Watson \\
\hline 1 & $.506^{\mathrm{a}}$ & .256 & 2.286 \\
\hline
\end{tabular}

Berdasarkan table diatas, diperoleh nilai $R$ Square sebesar 0,256, yang berarti kemampuan variable independen ROA, NPM, dan DER dalam mengungkapkan CSR sebesar 25,6\% sedangkan sisanya sebesar 74,4\% dipengaruhi oleh variable lain yang tidak termasuk dalam penelitian ini.

c. Uji t

Tabel 8

Hasil Uji t

\begin{tabular}{|c|c|c|c|c|c|}
\hline Model & B & $\begin{array}{l}\text { Std. } \\
\text { Error }\end{array}$ & Beta & $\mathrm{t}$ & ig \\
\hline $\begin{array}{ll}1 & \text { (Cons } \\
& \text { tant })\end{array}$ & .258 & .056 & & 4.594 & .000 \\
\hline $\mathrm{ROA}$ & -2.718 & 1.124 & -.753 & -2.418 & .022 \\
\hline NPM & 2.288 & 1.075 & .633 & 2.129 & .041 \\
\hline DER & .312 & .126 & .447 & 2.475 & .019 \\
\hline
\end{tabular}

a. Dependent Variabel: CSR

1. H1 ROA berpengaruh negatif signifikan terhadap CSR

Berdasarkan hasil uji t pada tabel diatas, uji statistik $t$ variable independen ROA memiliki thitung $>$ ttabel yaitu sebesar -2,418>-2,0369 dan nilai signifikansi $\quad 0,022<$ dari $\quad 0,05$. Maka hasilnya adalah variabel ROA berpengaruh negatif signifikan. Jadi hipotesis pertama yang menyatakan ROA 
berpengaruh positif signifkan terhadap CSR bertolak belakang dengan hasil uji t yang menyatakan ROA berpengaruh negative signifikan.

2. H2 NPM berpengaruh positif signifikan terhadap CSR

Berdasarkan hasil uji t pada tabel diatas, uji statistik $t$ variable independen NPM memiliki thitung $>$ ttabel yaitu sebesar 2,129>2,0369 dan nilai signifikansi $0,041<0,05$. Berdasarkan hal tersebut maka Ha diterima dan H0 ditolak. Maka hasilnya adalah variabel NPM berpengaruh positif signifikan. Jadi hipotesis kedua yang menyatakan NPM berpengaruh positif signifkan terhadap CSR diterima.

\section{H3 DER berpengaruh positif signifikan terhadap CSR}

Berdasarkan hasil uji t pada tabel diatas, uji statstik $t$ variable independen DER memiliki thitung>ttabel yaitu sebesar 2,475>2,0369 dan nilai signifikansi $0,019<0,05$. Berdasarkan hal tersebut maka $\mathrm{Ha}$ diterima dan $\mathrm{H} 0$ ditolaka. Maka hasilnya adalah variabel DER berpengaruh positif signifikan. Jadi hipotesis ketiga yang menyatakan DER berpengaruh positif signifkan terhadap CSR diterima.

\section{H4 ROA, NPM, dan DER} berpengaruh secara simultan terhadap CSR

Berdasarkan table diatas dapat kita lihat bahwa uji simultan pada penelitian ini menghasilkan nilai f hitung sebesar $3,565>$ f table $(2,87)$ dan signifikan hitung $0,025<0,05$. Ini menunjukkan bahwa variable independen yang antara lain return on aset (ROA), net profit margin (NPM), dan debt to equity ratio (DER) secara keseluruhan mempengaruhi pengungkapan corporate social responsbility (CSR). Jadi hipotesis ke empat yang menyatakan ROA, NPM, dan DER berpengaruh secara simultan terhadap pengungkapan CSR diterima.

\section{PEMBAHASAN}

\section{Pengaruh ROA terhadap CSR}

Hasil Penelitian didapatkan variabel ROA memiliki nilai pada hasil uji statistik $\mathrm{t}$ pada tabel 4.9, uji statistik $\mathrm{t}$ variabel independen ROA, dengan thitung>ttabel yaitu sebesar $-2,418>$ 2,0369 dan nilai signifikansi $0,022<0,05$ (5\%). Maka hasilnya adalah variabel ROA berpengaruh negatif signifikan. Jadi hipotesis pertama yang menyatakan ROA berpengaruh positif signifkan terhadap CSR bertolak belakang dengan hasil uji $t$ yang menyatakan ROA berpengaruh negative signifikan atau tidak berpengaruh positif namun signifikan yang berarti semakin tinggi ROA maka semakin sedikit nilai CSR yang diungkapkan.

Hal ini dapat dilihat pada nilai ROA yang terdapat di perusahaan Aneka Tambang Tbk yaitu sebesar $0,02 \%$ dan nilai CSR yang diungkapkan sebesar $0,54 \%$. Begitu juga sebaliknya pada perusahaan Bukit Asam Tbk yang memiliki nilai ROA sebesar $0,20 \%$ dan nilai CSR yang diungkapkan hanyA $0,14 \%$. Jadi dapat dikatakan nilai yang ada atau yang terjadi di lapangan yaitu di laporan perusahaan memang membuktikan bahwa rata-rata nilai ROA pada perusahaan pertambangan bernilai kecil yang membuat pengungkapan pada CSR menjadi meningkat, demikian juga terjadi sebaliknya, jika nilai ROA pada perusahaan tersebut bernilai besar maka pengungkapan CSR menurun. Hal ini membuktikan pengembalian laba dengan total asset yang ada berbanding terbalik 
dengan pengungkapan tanggungjawab social.

Hubungan antara ROA dengan CSR dapat diketahui sebagaimana fungsi dari Return On Assets (ROA) menurut Munawir (2007) itu sendiri yaitu dapat digunakan sebagian dasar untuk pengembalian keputusan kalau perusahaan akan mengadakan ekspansi atau mengumumkan tentang kinerja keuangan perusahaan kepada masyarakat luas. Maka ROA juga menggambarkan tingkat kesuksesan perusahaan itu sendiri.

Berdasarkan teori legitimasi (Gray, Kouhy dan Lavers, 1997) yang berkaitan langsung dengan kinerja keuangan khususnya profitabilitas yang diukur dengan ROA maka perusahaan akan menunjukkan tingkat kesuksesannya melalui hasil (return) yang dapat diukur dengan Return of Aset (ROA) yaitu perbandingkan tingkat laba dengan total aset perusahaan. Maka semakin tinggi tingkat keuntungan perusahaan semakin tinggi pula tingkat perusahaan akan mengungkapkan tanggung jawab sosial atau CSR, namun tidak pada penelitian ini, karena pada kenyataannya pengembalian tingkat laba dengan total asset bertolak belakang dengan penungkapan CSR.

Untuk itu dapat disimpulkan bahwa variabel ROA berpengaruh negative dan signifikan terhadap CSR. Selanjutnya penelitian ini juga membuktikan bahwa jika nilai ROA ditingkatkan maka akan berpengaruh negative terhadap pengungkapan CSR pada perusahaan pertambangan.

Hasil penelitian ini berarti sejalan dan sependapat dengan Penelitian Natalia, Johny, dan Joanne (2018) yang berjudul Pengaruh Kinerja Keuangan Terhadap Tanggung Jawab Sosial Perusahaan atau
Corporate Social Responsbility (CSR) Pada Perusahaan Tambang Yang Terdaftar di Bursa Efek Indonesia Periode 2015-2016 yang menyatakan return on asset dan net profit margin tidak berpengaruh positif signifikan terhadap corporate social responsibility (CSR).

Dengan adanya penelitian ini membuktikan bahwa variabel ROA memiliki pengaruh negatif signifikan atau tidak berpengaruh positif signifikan terhadap CSR pada perusahaan pertambangan.

\section{Pengaruh NPM terhadap CSR}

Hasil Penelitian didapatkan variabel NPM memiliki nilai pada hasil uji statistik $\mathrm{t}$ variable independen NPM memiliki thitung>ttabel yaitu sebesar 2,129>2,0369 dan nilai signifikansi $0,041<0,05$. Berdasarkan hal tersebut maka Ha diterima dan $\mathrm{HO}$ ditolak. Maka hasilnya adalah variabel NPM berpengaruh positif signifikan. Jadi hipotesis kedua yang menyatakan NPM berpengaruh positif signifkan terhadap CSR diterima.

Nilai yang tercantum pada laporan perusahaan memang membuktikan bahwa jika rata-rata nilai NPM pada perusahaan pertambangan bernilai besar akan membuat pengungkapan pada CSR menjadi meningkat, demikian juga terjadi sebaliknya, jika nilai NPM pada perusahaan tersebut bernilai kecil maka pengungkapan CSR menurun. Hal ini membuktikan pengembalian laba dengan total penjualan yang ada berpengaruh pada pengungkapan tanggungjawab social perusahaan.

Hubungan NPM dengan pengungkapan CSR dapat dilihat dengan mengelola reputasi kinerja keuangan perusahaan melalui laporan keuangan 
perusahaan yaitu tingkat laba yang tinggi dengan mengukur net profit margin, maka perusahaan akan secara otomatis memiliki pandangan sukses dalam kinerja keuangannya termasuk dalam pengungkapan CSR. Maka NPM sangat berhubungan erat dengan pengungkapan CSR, yaitu dengan tingkat laba atau profit dengan total penjualan yang tinggi maka pengungkapan CSR dalam perusahaan pertambangan akan semakin tinggi.

Berdasarkan teori legitimasi (Gray, Kouhy dan Lavers, 1997) yang berkaitan langsung dengan kinerja keuangan khususnya profitabilitas yang diukur dengan NPM, hasil penelitian ini adalah perusahaan menunjukkan tingkat kesuksesannya melalui laba atau profit yang dapat diukur dengan Net Profit Margin (NPM) yaitu perbandingkan tingkat laba dengan penjualan. Maka semakin tinggi tingkat keuntungan perusahaan semakin tinggi pula tingkat perusahaan akan mengungkapkan tanggung jawab sosial atau CSR. Untuk itu dapat disimpulkan bahwa variabel NPM berpengaruh positif dan signifikan terhadap CSR. Selanjutnya penelitian ini juga membuktikan bahwa jika NPM ditingkatkan bisa jadi meningkatkan pengaruh terhadap CSR pada perusahaan pertambangan.

Hasil penelitian ini sependapat dan sejalan dengan penelitian Rita Anugerah dkk (2010) yang berjudul Pengaruh Ukuran Perusahaan, Leverage, dan Profitabilitas Terhadap Pengungkapan Tanggung Jawab Sosial Perusahaan Pada Perusahaan Manufaktur Yang Listing Di BEI yang menyatakan bahwa NPM berpengaruh positif signifikan terhadap pengungkapan tanggung jawab sosial atau CSR. Dengan adanya penelitian ini membuktikan bahwa variabel NPM memiliki pengaruh positif signifikan terhadap CSR pada perusahaan pertambangan.

\section{Pengaruh DER terhadap CSR}

Hasil Penelitian didapatkan variabel DER memiliki nilai pada hasil uji statistik $\mathrm{t}$ yang memiliki thitung $>$ ttabel yaitu sebesar 2,475>2,0369 dan nilai signifikansi $0,019<0,05$. Berdasarkan hal tersebut maka Ha diterima dan $\mathrm{H} 0$ ditolak. Maka hasilnya adalah variabel DER berpengaruh positif signifikan. Jadi hipotesis ketiga yang menyatakan DER berpengaruh positif signifkan terhadap CSR diterima.

Nilai yang tercantum pada laporan perusahaan juga membuktikan bahwa jika rata-rata nilai DER pada perusahaan pertambangan bernilai besar akan membuat pengungkapan pada CSR menjadi meningkat, demikian juga terjadi sebaliknya, jika nilai DER pada perusahaan tersebut bernilai kecil maka pengungkapan CSR menurun. Hal ini membuktikan pengembalian total kewajiban atau hutang dengan total modal yang ada berpengaruh pada pengungkapan tanggungjawab social perusahaan.

Hubungan DER dengan CSR dapat dilihat melalui fungsi dari DER itu sendiri yaitu rasio Leverage yang diukur dengan DER merupakan alat untuk mengukur seberapa besar perusahaan bergantung kepada kreditur dalam pembiayaan aset perusahaan. Melalui tingkat leverage yang diukur dengan DER perusahaan dapat diketahui seberapa besar utang perusahaan kepada kreditur. Tingkat kemampuan mengembalikan seluruh total hutang atau kewajiban dengan menggunakan dengan total modal yang dimiliki perusahaan, maka hal 
tersebut menggambarkan tingkat perkembangan perusahaan yang baik.

Penelitian ini terbukti dengan teori yang digunakan yaitu stakeholder, Teori stakeholder adalah teori yang menggambarkan kepada pihak mana saja perusahaan bertanggungjawab (Freeman, 1983). Teori ini berhubungan dengan DER karena berhubungan langsung dengan pemilik modal atau pihak yang bertanggung jawab dalam perusahaan. DER adalah Debt to Equity Ratio atau dalam bahasa Indonesia disebut dengan Rasio Hutang terhadap Ekuitas atau Rasio Hutang Modal yaitu suatu rasio keuangan yang menunjukan proporsi relatif antara Ekuitas dan Hutang yang digunakan untuk membiayai perusahaan. Dari hasil penelitian ini rasio DER atau tingkat melunasi seluruh hutang dengan total modal yang dimiliki sudah terbilang cukup baik.

Untuk itu dapat disimpulkan bahwa variabel DER berpengaruh positif dan signifikan terhadap CSR. Selanjutnya penelitian ini juga membuktikan bahwa jika rasio DER ditingkatkan bisa jadi meningkatkan pengaruh terhadap CSR pada perusahaan pertambangan.

Hasil penelitian ini sejalan dan sependapat dengan penelitian Cahya (2010) yang berjudul Analisis Pengaruh Kinerja Keuangan Terhadap Tanggung Jawab Sosial Perusahaan (Corporate Social Responsbility) yang menyatakan bahwa leverage yang diukur dengan DER berpengaruh positif signifikan terhadap pengungkapan tanggung jawab sosial atau CSR.

Dengan adanya penelitian ini membuktikan bahwa variabel DER memiliki pengaruh positif signifikan terhadap CSR pada perusahaan pertambangan.

\section{Pengaruh ROA, NPM, dan DER terhadap CSR}

Berdasarkan hasil uji f dapat kita lihat bahwa uji simultan ini menghasilkan nilai f hitung sebesar 3,565>f table $(2,87)$ dan signifikan hitung $0,025<0,05$. Ini menunjukkan bahwa variable independen yang antara lain Return On Aset (ROA), Net Profit Margin (NPM), dan Debt to Equity Ratio (DER) secara keseluruhan mempengaruhi pengungkapan Corporate Social Responsbility (CSR). Jadi hipotesis ke empat yang menyatakan ROA, NPM, dan DER berpengaruh secara simultan terhadap pengungkapan CSR. Ha diterima dan $\mathrm{H} 0$ ditolak yang artinya adalah $\mathrm{H} 4$ diterima.

Berdasarkan hubungan dari ketiga variabel independen tersebut, maka semakin tinggi rasio dengan tingkat pengembalian laba atau hutang dengan total modal pada perusahaan maka perusahaan tersebut wajib mengungkapkan CSR perusahaan melalui laporan tahunan atau laporan keberlanjutan, sebagai bentuk tanggung jawab sosialnya.

Hasil penelitian ini sejalan dan sependapat dengan penelitian Sari (2012) yang menemukan bahwa profitabilitas yang diukur dengan ROA dan NPM berpengaruh negatif signifikan atau tidak berpengaruh positif signifikan terhadap corporate social responsibility (CSR) dan penelitian Cahya (2010) menyatakan bahwa leverage yang diukur dengan DER berpengaruh positif signifikan terhadap pengungkapan tanggung jawab sosial atau CSR.

Dengan adanya penelitian ini membuktikan bahwa variabel ROA, 
NPM, dan DER secara simultan memiliki pengaruh positif signifikan terhadap CSR pada perusahaan pertambangan.

\section{KESIMPULAN DAN SARAN}

\section{Kesimpulan}

1. ROA berpengaruh negatif dan signifikan atau tidak berpengaruh positif dan signifikan terhadap CSR.

2. NPM berpengaruh positif dan signifikan terhadap CSR

3. DER berpengaruh positif dan signifikan terhadap CSR.

4. ROA, NPM dan DER bersama-sama berpengaruh signifikan secara simultan terhadap CSR.

\section{Saran}

Mengacu pada hasil penelitian maka penulis memberikan saran sebagai berikut:

1. Memperluas penelitian dengan cara memperpanjang periode penelitian dengan menambah tahun pengamatan dan memperbanyak jumlah sampel untuk penelitian yang akan datang.

2. Penelitian yang akan datang juga sebaiknya menambah variabel independen yang masih berbasis pada data laporan keuangan atau rasio keuangan selain yang digunakan dalam penelitian ini dengan tetap berlandaskan pada penelitian-penelitian sebelumnya.

3. Diharapkan bagi perusahaan pertambangan mampu menungkapkan CSR dengan tingkat yang lebih baik dan meningkatkan tanggungjawab sosial perusahaan terhadap masyarakat sekitar.

\section{DAFTAR PUSTAKA}

Arikunto, S. 2010. Prosedur Penelitian Suatu Pendekatan Praktik. Jakarta: Rineka Cipta.

Vol. 11, No. 1, Juli 2020, Halaman 59-70
Cahya, Adi Bramantya. 2010. Analisis Pengaruh Kinerja Keuangan Terhadap Tanggung Jawab Sosial Perusahaan (Corporate Social Responsibility). Skripsi Akuntansi UNDIP: Semarang.

Darwin, Ali. 2006. Laporan Keberlanjutan Kompetensi Baru Profesi Akuntan Manajemen. Edisi II April September. Economic Business Review: Jakarta.

Gray, Kouhy dan Lavers. 1997. Corporate Social and Environmental Reporting: A Review of The Literature and A Longitudional Study of UK Disclosure. Accounting, Auditing and Accountability Journal. Vol.8, No.2. pp: 47-77.

Istiana Chrisma. 2016. Pengaruh Karakteristik Perusahaan Terhadap Corporate Social Responsibility Disclosure (Studi Empiris Perusahaan Manufaktur Terdaftar Di Bursa Efek Indonesia Periode 2013-2014). Skripsi.Universitas Muhamadiyah Surakarta.

Kasmir. 2014. Analisis Laporan Keuangan. Jakarta: Raja Grafindo Persada.

Masterplan Percepatan Dan Perluasan Pembangunan Ekonomi Indonesia 2011-2025.

Munawir. 2007. Analisa Laporan Keuangan. Edisi Empat Liberty: Yogyakarta.

Natalia, Johny, dan Joanne. 2018. Pengaruh Kinerja Keuangan Terhadap Tanggung Jawab Sosial Perusaahaan (Corporate Social Responsibility) Pada Perusahaan Tambang Yang Terdaftar Di Bursa Efek Indonesia Periode 2015-2016. Jurnal Administrasi Bisnis Vol. 6 No. 2 Tahun 2018.

Rita Anugerah, Roland Hutabarat, Dan W. Faradilla. 2010. Pengaruh Ukuran Perusahaan, Leverage Dan Profitabilitas Terhadap Pengungkapan Tanggung Jawab Sosial Perusahaan Pada Perusahaan Manufaktur Yang 
Listing Dibei. Jumal Ekonomi Volume

18, Nomor 1 Maret 2010.

Sari, Rizkia. 2012. Pengaruh Karakteristik Perusahaan Terhadap Corporate Social Responsibility Disclosure Pada Perusahaan Manufaktur Yang Terdaftar Di Bursa Efek Indonesia. Jurnal Nominal / Volume I Nomor I / Tahun 2012.

Syahnaz, Melisa. 2013. Pengaruh Pengungkapan Corporate Social Responsbility Terhadap Kinerja Keuangan Perusahaan Perbankan. Jurnal Akuntansi Vol 1 No 2 Fakultas Ekonomi dan Bisnis Universitas Brawijaya.

Yuansyah.2012.

Http://Www.Neraca.Co.Id/Article/218

17/Perusahaan-Tambang-DimintaTerapkan-Csr-Lingkungan-RentanPencemaran.DiaksesPadaTanggal 28 April 2019. 